\title{
ALA Midwinter Meeting Highlights
}

Under old business there were two bylaws amendments passed by Steering that were presented to Membership. The first was to create the possibility for Interest Groups within GODORT. There was some concern about the make-up of Steering if all the task forces move to become interest groups. This motion carried. The second amendment was for the creation of a Virtual Meetings Coordinator position. This motion carried.

Under new business the John Shuler Memorial Resolution was approved unanimously. Also under new business chair Sarah Erekson asked members to consider what government information librarianship looks like now and what directions we want to move to while we go through our reorganization.

\section{Steering I-II Meetings}

Steering I was held virtually a couple of weeks before Midwinter. Steering voted to approve the IFLA GIOPS appointment of Geoff Swindells for a second term. Samantha provided information on how to conduct virtual meetings at Midwinter. It was also noted that ALA was planning a conference redesign for the New Orleans conference and there was some concern about roundtable programs not listed. Steering was asked to look at having some GODORT publications that are digitized in HathiTrust be made open access.
At Steering II there were some updates on ALA's conference redesign. There is now an FAQ (http://connect .ala.org/node/262302) and members can provide their own opinions at http://con nect.ala.org/node/261211.

Under old business there was another bylaws amendment to create an officer to replace the bylaws committee. The five-year plan was to sunset the committee and to have just a bylaws officer/coordinator who would be a voting member.

Under new business there was a discussion on the virtual Steering I meeting and that committees should focus on bringing government information to the ALA organization. 